\title{
Kan Nederland op zijn accountants rekenen?
}

\author{
Oscar van Leeuwen
}

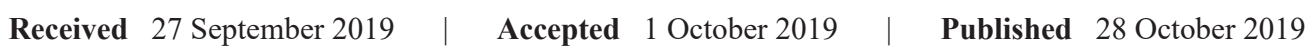

\section{Inleiding}

Op 10 september 2019 trapte de Nederlandse Beroepsorganisatie van Accountants (NBA) de campagne Nederland rekent op zijn accountants, af met een paginagrote advertentie in het Financieel Dagblad. Met deze campagne die op de radio te horen is via BNR Nieuwsradio en Radio 1 wil de NBA het imago van de accountant verbeteren en de relevantie van het beroep voor de samenleving versterken. Inzet van de campagne is dat een groter deel van de samenleving het publiek belang van de rol van de accountant erkent. Immers: accountants staan borg voor het publiek belang.

Een accountant voert een accountantscontrole uit om zekerheid te verschaffen over de getrouwheid van de informatie in de jaarrekening. Het bestuur (de aandeelhoudersvergadering) van een organisatie kan een accountant aanstellen voor het uitvoeren van een accountantscontrole van de jaarrekening van deze organisatie. De accountants die de wettelijk controle uitvoeren moeten verbonden zijn aan een accountantsorganisatie die ingeschreven is in het register van de Autoriteit Financiële Markten (AFM).

\section{Wanneer is het inschakelen van een accountant verplicht?}

Sommige organisaties zijn wettelijk verplicht zich door een accountant te laten controleren.

Rechtspersonen die gedurende twee opeenvolgende jaren voldoen aan minimaal twee van de volgende drie kengetallen zijn (op enkele uitzonderingen na) verplicht om een accountantscontrole te laten uitvoeren:

- een omzet van minimaal EUR 12 miljoen;

- een balanstotaal van minimaal EUR 6 miljoen;

- minimaal 50 werknemers.

\section{Wat gebeurt er als je geen accountant inschakelt, terwijl je dit wel verplicht bent?}

Het niet nakomen van de controleplicht is een economisch delict en strafbaar. De maximale boete beloopt EUR 19.500, zes maanden hechtenis of een taakstraf voor de bestuurders van de rechtspersoon. Daarnaast heeft het niet nakomen van de controleplicht gevolgen voor de bestuurdersaansprakelijkheid. Dit laatste kan verstrekkende gevolgen hebben in het geval van een faillissement.

Maar er is meer: als lagere overheden zoals een gemeente of een provincie geen goedkeurende controleverklaring kunnen overleggen krijgen ze geen middelen van het Rijk toegewezen. Dit overkwam bijvoorbeeld de Provincie Utrecht afgelopen jaar.

Ook bankkredieten zijn vaak gekoppeld aan het verkrijgen van een goedkeurende controleverklaring.

Kortom: je kunt er als organisatie maar beter voor zorgen dat je een goedkeurende controleverklaring hebt. Goed dat de NBA een campagne start dat Nederland op zijn accountants kan rekenen!

\section{Kan Nederland wel op zijn accountants rekenen?}

Hetzelfde Financieel Dagblad (FD) waar op 10 september de campagne Nederland rekent op zijn accountants in werd afgetrapt kopt op 18 september echter: "Kleintjes op de beurs kunnen door nieuwe wet geen accountant krijgen". Een aantal kleinere beursfondsen kan geen accountant vinden vanwege de krappe markt. In diezelfde week kreeg een adviesrelatie van mij te horen dat de zittend accountant komend jaar niet genoeg mensen had om de controle uit te voeren. Pas medio 2020 had het accountantskantoor weer tijd. 


\section{Hoe komt dit?}

In het artikel in het FD worden hiervoor twee oorzaken genoemd:

a. de vraag naar gespecialiseerde accountants die organisaties van openbaar belang mogen controleren stijgt omdat sinds januari van dit jaar meer organisaties zijn aangemerkt als organisaties van openbaar belang (oob). Ook elektriciteitsnetbeheerders, grotere woningcorporaties en enkele instanties voor wetenschappelijk beleid en grotere pensioenfondsen worden aangemerkt als organisaties van openbaar belang. Banken, verzekeraars en beursgenoteerde bedrijven hoorden al tot deze categorie bedrijven.

b. Voor het controleren van oob's is een extra vergunning vereist. Het aanbod van accountants dat oob's mag controleren is echter gedaald, omdat drie van de negen accountantsorganisaties met een oob-vergunning recentelijk hun licentie hebben ingeleverd. Het betreft Baker Tilly, Grant Thornton en Accon AVM. De zes resterende accountantsorganisaties hebben onvoldoende tijd om de hele markt te bedienen.

De organisaties die wel een accountant kunnen krijgen betalen als gevolg van het krappe aanbod de hoofdprijs. Dit is een gevolg van de vrije markt voor het aanbieden van de accountantsdiensten. De accountantsorganisaties hebben nu de keuze welke klanten zij willen hebben. De accountantsorganisaties zullen kiezen voor klanten met een laag risicoprofiel waar zij de hoogste prijs voor kunnen krijgen. Wie kan hen dat kwalijk nemen?.

Daarnaast hebben accountants het moeilijk voldoende personeel te kunnen krijgen. In mei 2018 werd een onderzoek gepubliceerd waaruit blijkt dat jonge professionals werkzaam bij accountantsorganisaties de werkdruk te hoog vinden. Zij moeten naar hun gevoel te hard werken om de winsten van de accountantsorganisaties op een voldoende niveau te houden. Het beroep wordt dus minder aantrekkelijk. Dit leidt weer tot een hoger verloop en minder starters die bij een accountantsorganisatie willen beginnen. Kortom: een spiraal naar beneden.

In tegenstelling tot de slogan van NBA-campagne kan Nederland op dit moment dus helaas niet altijd op zijn accountants rekenen. De combinatie van een wettelijke controleplicht en te weinig beschikbare capaciteit bij accountants leiden tot het niet uitvoeren van verplichte accountantscontroles. Organisaties met een vanuit maatschappelijke optiek hoger risicoprofiel kunnen geen accountant vinden. Dit roept de vraag op of het wel maatschappelijk gewenst is dat organisaties met een hoger risicoprofiel geen accountant kunnen krijgen. Ik denk zelf dat juist bij deze groep organisaties een controleverklaring belangrijk is voor het maatschappelijk verkeer en dus deze groep organisaties wel een controleverklaring zou moeten krijgen.

\section{Wat kunnen wij er aan doen?}

De gevolgen zijn groot. De organisatie kan niet voldoen aan zijn wettelijke verplichting een accountant aan te stellen en ondervindt daarvan de negatieve gevolgen. Organisaties die geen accountant hebben zullen er dus wel een willen vinden.

In Accountant van september 2019 wordt in een interview met Herman van Brenk en Remko Renes aandacht besteed aan het idee een onafhankelijke marktmeester in te stellen voor oob-organisaties. Die marktmeester (Audit Board genoemd) zonder winstoogmerk, heeft eigen mensen, maar leent ook personeel in van accountantsorganisaties (zogenaamde Audit Board Fellows).

Naar mijn gevoel kan een dergelijke Audit Board een oplossing zijn voor de huidige tendens om alleen organisaties met een laag risicoprofiel te controleren. Daarmee wordt een deel van het probleem opgelost.

Het tekort aan controlerende medewerkers wordt hierdoor echter op korte termijn niet opgelost.

Uiteindelijk zullen accountantsorganisaties aantrekkelijker moeten worden voor hun medewerkers. Als zij meer mensen aannemen en deze minder uren laten werken wordt het ook voor jonge professionals weer aantrekkelijker. De partners van de accountantsorganisaties zullen als gevolg hiervan dan wel genoegen moeten nemen met een wat lagere beloning.

Aangezien dit momenteel kennelijk onvoldoende gebeurt zou het oplossen van dit probleem naar mijn mening onderdeel uit moeten maken van het onderzoek dat wordt uitgevoerd door de Commissie Toekomst Accountancysector die eind van dit jaar haar aanbevelingen publiceert.

In de tussenrapportage van de Commissie Toekomst Accountancy sector van 1 oktober 2019 concludeert de Commissie onder andere: "om te voorkomen dat een controleplichtige onderneming - ondanks gerede inspanning - er niet in slaagt een accountant te contracteren krijgt de toezichthouder of de meest betrokken minister de bevoegdheid een aanwijzing te geven waarbij een accountantsorganisatie aan een controle cliënt wordt toegewezen".

Als de campagne Nederland rekent op zijn accountants er uiteindelijk toe leidt dat meer mensen zich tot het accountantsberoep aangetrokken voelen helpt dit natuurlijk ook.

Op korte termijn zijn de organisaties die zonder accountant zitten hier niet mee geholpen. Noblesse oblige: naar mijn mening zou de NBA in overleg met de AFM samen met de accountantsorganisaties de komende maanden iets aan dit probleem moeten doen. 
- Prof. dr. O.C. van Leeuwen RA is werkzaam als hoogleraar Bestuurlijke Informatieverzorging/Administratieve organisatie aan de Vrije Universiteit Amsterdam. Daarnaast is hij werkzaam als partner bij het adviesbureau Improven.

\section{Literatuur}

- Baurichter R, Zannergen L (2019) Kleintjes op de beurs kunnen door nieuwe wet geen accountant krijgen. Het Financieele Dagblad, 18 september 2019. https://www.accountant.nl/nieuws/2019/9/kleintjesop-de-beurs-kunnen-door-nieuwe-wet-geen-accountant-krijgen-fd/

- Van Brenk H, Renes R (2019) Twee meesters of één audit board? Interview Herman van Brenk en Remko Renes. Accountant (septem- ber 2019, Q3): 28-33. https://www.accountant.nl/magazines/accountant-2019-q3/

- Ottow A, Dijkgraaf E, De Vries M (2019) Voorlopige bevindingen Commissie Toekomst Accountancy Sector. 1 oktober 2019. https:// www.internetconsultatie.nl/voorlopigebevindingencta 